\title{
Bionic pancreas: the first results of functionality bionic tissue model with pancreatic islets
}

\author{
Michal Wszola', Marta Klak, Anna Kosowska², Joanna Olkowska-Truchanowicz ${ }^{3}$, Grzegorz Tymicki ${ }^{1}$, Andrzej Berman ${ }^{1}$, \\ Tomasz Bryniarski ${ }^{1}$, Marta Kołodziejska ${ }^{1}$, Izabela Uchrynowska-Tyszkiewicz ${ }^{3}$, Artur Kamiński ${ }^{3}$ \\ ${ }^{1}$ Foundation of Research and Science Development, Warsaw, Poland \\ ${ }^{2}$ Department of Histology and Embryology, Medical University of Warsaw, Warsaw, Poland \\ ${ }^{3}$ Department of Transplantology and Central Tissue Bank, Medical University of Warsaw, Warsaw, Poland
}

Background: Three-dimensional (3D)-bioprinting using living cells is the latest technique in the field of biomedical engineering. One of the most important points of the procedure is preserving the cells and leaving them fully functional in the resulting bioconstruction. In the case of bioprinting of bionic tissue, it is important to provide cells with access to nutrients and gas exchange. These are the first results of printed bionic petals and the first studies on a mouse model.

Methods: Research was carried out on 60 mice (severe combined immune deficient [SCID]). Diabetes induction was not undertaken in animal studies because T1D is difficult to achieve in a mouse model. The mice were divided into three groups: control; IsletTx in which porcine pancreatic islets were transplanted under the renal capsule; and 3D-bioprint in which bioink petals consisted of bioink $A$ and porcine islets. The petals were transplanted into the dorsal part of the muscles under the skin. Daily glucose measurement was performed and the level of C-peptide was tested every 7 days.

Results: The results obtained in mice initially showed no differences in the concentration of peptide- $C$ and glucose between groups. However, as early as 7-days after transplantation, both parameters analyzed in the fasting state were significantly lower in the IsletsTx and 3D-bioprinted groups compared to the control group. On day 14, decreased values of C-peptide and glucose were observed only in the group with petals transplants.

Conclusions: Transplantation of bionic petals in mice resulted in a decrease in mean glucose levels. The mice showed a reduced concentration of their own C-peptide, which can indicate relief in mice's owns islets function. None of the animals died due to postoperative complications or the lack of biocompatibility with the bionic structure. Positive effect of transplantation was maintained throughout the experiment, which proves the optimal selection of the composition of the bioink and bioprinting parameters.

Corresponding author: Michal Wszola

E-mail: michal.wszola@fundacjabirn.pl

(c) The Korean Society for Transplantation

This is an Open Access article distributed under the terms of the Creative Commons Attribution Non-Commercial License (http://creativecommons.org/licenses/by-nc/4.0/) which permits unrestricted non-commercial use, distribution, and reproduction in any medium, provided the original work is properly cited. 